\title{
Pengembangan Produk Unggulan Sebagai Potensi Peningkatan Ekonomi Masyarakat Desa di Kecamatan Modung Bangkalan
}

\author{
Moh. Jufriyanto \\ Program Studi Teknik Industri Fakultas Teknik \\ Universitas Trunojoyo Madura \\ E-mail : jufriyanto@trunojoyo.ac.id \\ DOI: http://dx.doi.org/10.21107/pgd.v5i1.5162
}

\begin{abstract}
Artikel Diterima : 10 November 2018/ Revisi : 14 Februari 2019/Terbit : 15 April 2019
Abstrak

Salah satu cara dalam pembangunan ekonomi ini dengan mengoptimalkan produk unggulan atau komoditas unggulan. Produk unggulan ini akan memberikan manfaat dalam pengoptimalan sumber daya yang ada dan mampu memberikan suatu pengetahuan tentang suatu bahan yang memiliki nilai ekonomis lebih. Selain itu, dengan adanya produk unggulan mampu menimbulkan potensi peningkatan ekonomi masyarakat suatu wilayah tersebut. Kegiatan produk unggulan desa ini dilakukan pada kegiatan Kuliah Kerja Nyata (KKN). Lokasi pelaksanaan yaitu di 3 desa Kecamatan Modung, Bangkalan. 3 desa tersebut yaitu Desa Paeng, Patereman dan Neroh. Kegiatan KKN berlangsung \pm 1 bulan. Tempat pelaksaan di masing-masing kediaman Kepala Desa. Hasil dari kegiatan produk unggulan desa yaitu menemukan potensi yang ada di wilayah tersebut dan dijadikan sebuah produk yang memiliki nilai ekonomis yang tinggi. Hasil produk unggulan dari masing-masing desa yaitu, Produk unggulan dari Desa Paeng yaitu selai jagung dan puding jagung. Produk unggulan Desa Patereman yaitu, selai sawo dan keripik sawo. Produk unggulan Desa Neroh yaitu, stik nasi, kerupuk nasi dan selai kacang. Produk unggulan yang diciptakan merupakan potensi yang ada di wilayah tersebut seperti kacang, jagung, sawo dan padi.
\end{abstract}

Kata Kunci : pembangunan desa, produk unggulan, kuliah kerja nyata

\section{PENDAHULUAN}

Permasalahan tentang perekonomian sangatlah penting. Hal ini menandakan bahwa dengan meningkatnya perekonomian suatu daerah maka tingkat taraf kesejahteraan juga meningkat. Hal ini juga berhubungan dengan pembangunan ekonomi. Menurut Chuzaimah dan Mabruroh (2008) menyatakan bahwa pembangunana ekonomi adalah suatu proses dimana suatu masyarakat menciptakan suatu lingkungan yang mempengaruhi hasil-hasil indikator ekonomi seperti kenaikan kesempatan kerja, peningkatan pendapatan dan perbaikan taraf hidup. Lingkungan yang dimaksud sebagai sumber daya perencanaan meliputi tentang lingkungan fisik, peraturan dan perilaku.

Dalam pembangunan ekonomi terdapat kesenjangan ekonomi antar daerah yang berakibat pada rendahnya tingkat pendapatan masyarakat dan bahkan kemiskinan, adalah masalah yang belum terselesaikan. Dalam hal ini pembangunan masih berorientasi sektoral dan kurang memperhatikan karakteristik dan kondisi dari sumber daya suatu wilayah, sedangkan sumber-sumber daya pembangunan semakin terbatas (Yomalinda, 2014).
Menurut Pantow et.al (2015) menyatakan bahwa Pertumbuhan ekonomi mempunyai peranan yang sangat penting, sehingga perlu adanya perencanaan yang matang dalam meningkatkan kinerja dan orientasi pembangunan. Selain itu, menjamin keterkaitan dan konsi stensi antara perencanaan, penganggaran, pelaksanaan dan pengawasan sehingga dapat mengoptimalkan partisipasi masyarakat dalam perencanaan pembangunan untuk tercapainya pembangunan secara efisien dan efektif.

Dalam menghadapi permasalahan tersebut maka diperlukan pengoptimalan potensi wilayah baik dari sumber daya alam, sumber daya manusia serta sumber dana lainnya untuk pembangunan ekonomi daerahnya. Salah satu cara dalam pembangunan ekonomi ini dengan mengoptimalkan produk unggulan atau komoditas unggulan. Menurut Hidayah (2010) menyatakan bahwa komoditas unggulan adalah komoditas andalan yang memiliki posisi strategis untuk dikembangkan di suatu wilayah. Posisi strategis ini didasarkan pada pertimbangan teknis (kondisi tanah dan iklim), sosial ekonomi dan kelembagaan. 
Salah satu kegiatan untuk mengetahui permasalahan diatas adalah dengan langsung survey ke suatu wilayah. Kegiatan yang bisa dilakukan berupa penyuluhan, kulian kerja nyata dan sebagainya. Universitas Trunojoyo Madura dengan Lembaganya yaitu LPPM telah melakukan sutau kegiatan yaitu Kuliah Kerja Nyata yang dimasukkan dalam satuan mata kuliah yang wajib ditempuh oleh para mahasiswa yang kuliah di Universitas Trunojoyo Madura. Kuliah Kerja Nyata ini bertujuan untuk mengenalkan kepada mahasiswa tentang kehidupan masyarakat serta mampu menggali potensi unggulan suatu daerah yang mampu menjadi potensi peningkatan ekonomi masyarakat suatu wilayah tersebut.

Kegiatan Kuliah Kerja Nyata ini dilaksanakan kurang lebih selama 1 bulan. Harapan dari Kuliah Kerja Nyata ini, para mahasiswa dapat berkontribusi menerapkan ilmu yang mereka dapat selama dikampus. Selain itu, juga dapat menciptakan suatu potensi unggulan bagi suatu wilayah tersebut dalam pembangunan ekonomi dan kesejahteraan masyarakat tersebut. Produk unggulan ini akan memberikan manfaat bagi mereka dalam pengoptimalan sumber daya yang ada dan mampu memberikan suatu pengetahuan tentang suatu bahan yang memiliki nilai ekonomis lebih.

\section{METODE}

Dalam proses mengembangkan produk unggulan sebagai output dalam program Kuliah Kerja Nyata ini dilakukan beberapa tahapan yang dilakukan yaitu :

\section{a. Tahapan Identifikasi dan Persiapan}

- Melakukan survey ke lokasi Kuliah Kerja Nyata untuk melihat keadaan kondisi lingkungan sekitar.

- Melakukan proses wawancara dengan pihak lokasi tempat KKN untuk mengetahui sektor mana yang sering menjadi mata pencaharian masyarakat tersebut.

- Mengidentifikasi beberapa kegiatan yang pernah dilakukan oleh pihak terkait dalam menciptkan produk unggulan.

- Menentukan objek dan sektor mana yang akan dilakukan untuk mencipakan proudk unggulan.

- Melakukan kajian materi terhadap potensi unggulan yang ada.
- Menentukan kerangka kerja serta langkahlangkah dalam proses penysuna produk unggulan.

\section{b. Tahap Pelaksanaan}

- Menentukan peserta yaitu masyarakat lokasi KKN serta lembaga PKK yang ada dalam lokasi tersebut.

- Proses sosialisasi dengan praktek pengolahan potensi unggulan atau komoditas unggulan secara terbuka kepada masyarakan di lokasi KKN tersebut.

- Praktek pengolahan secara masing-masing oleh masyarakat pada saat pelaksanaan sosialisasi.

- Penambahan pengetahuan akan suatu komoditas unggulan yang memiliki nilai ekonomis yang tinggi serta bermanfaat bagi kesehatan tubuh manusia.

\section{HASIL DAN PEMBAHASAN}

Pada hasil dan pembahasan ini menjelaskan tentang hasil mahasiswa dalam menciptakan produk unggulan. Pada penjelasan ini tentang produk unggulan KKN yang berlokasi di kecamatan modung dengan objek 3 desa yaitu Desa Paeng untuk kelompok KKN 40, Desa Neroh untuk kelompok KKN 73 dan Desa Patereman untuk kelompok KKN 74. Semua kelompok KKN tersebut telah menciptakan produk unggulan di masing-masing desa tersebut. Adapun penjelasannya sebagai berikut :

\section{a. Produk unggulan Desa Paeng : Selai jagung dan Puding jagung (kelompok KKN 40)}

Kegiatan sosialisasi dan demonstrasi berlangsung pada tanggal 20 Januari 2019 bertempat di posko KKN 40 Desa Paeng. Rentetan acara diantaranya pembukaan, sosialisasi dan demonstrasi pembuatan produk unggulan berupa selai dan puding jagung, dilanjutkan dengan tanya jawab dari ibu-ibu warga desa Paeng dan penutup. Acara berjalan dengan baik dan warga sangat antusias terhadap produk unggulan desa dibuktikan dari banyaknya pertanyaan terhadap produk unggulan baik dari segi pengolahan maupun tips-tips agar puding maupun selai yang dihasilkan dapat mencapai hasil yang maksimal.

Desa Paeng merupakan desa penghasil jagung di kecamatan Modung Bangkalan. Jagung merupakan makanan pokok pengganti nasi dengan kandungan karbobidrat yang tinggi namun rendah gula sehingga baik dikonsumsi 
penderita diabetes. Dalam budaya masyarakat desa, jagung cenderung dikonsumsi dengan pengolahan sederhana seperti diolah menjadi jagung rebus, jagung bakar, nasi jagung atau bakwan jagung. Padahal, apabila jagung diolah dengan cara lain yang lebih kreatif maka akan menghasilkan produk olahan jagung yang lebih menarik dan memiliki nilai ekonomi yang lebih tinggi. Untuk itu, KKN 40 membuat inovasi dengan mengolah jagung menjadi produk olahan berupa puding dan selai jagung dengan nilai ekonomi yang lebih baik sehingga diharapkan mampu membantu meningkatkan nilai ekonomi masyarakat, khususnya masyarakat desa Paeng.

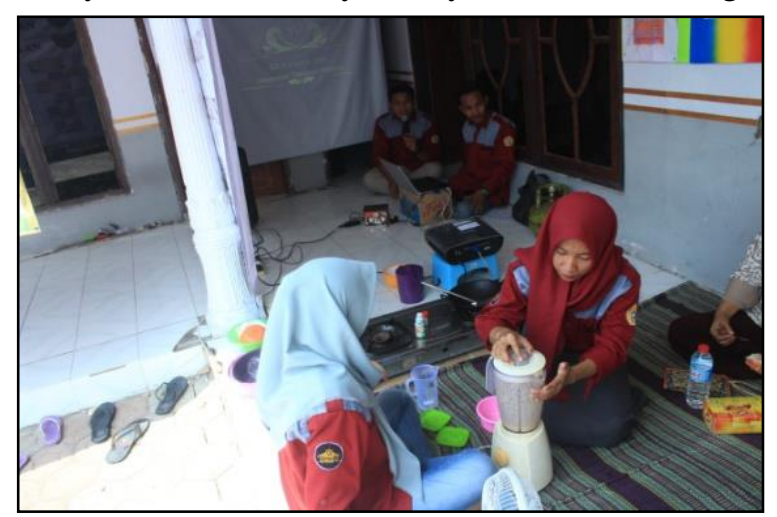

Gambar 1. Proses Pembuatan Puding dan Selai Jagung
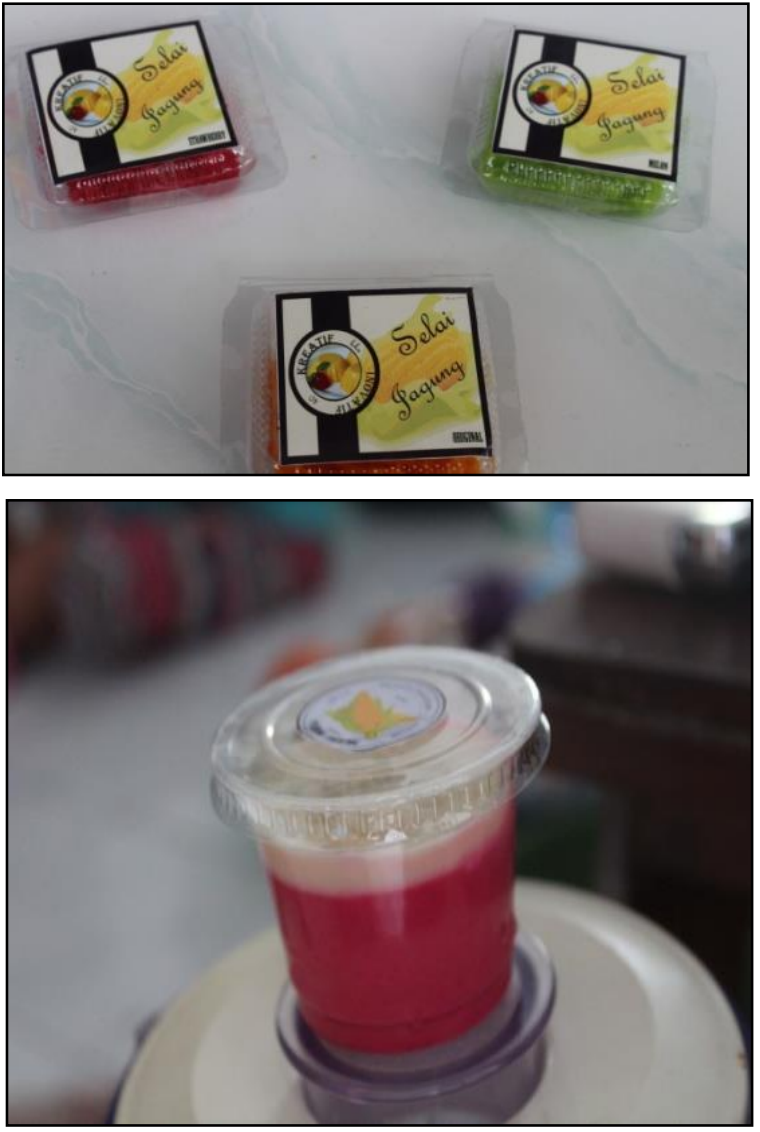

Gambar 2. Produk Selai dan Puding Jagung b. Produk unggulan Desa Patereman : Selai sawo dan Keripik sawo (kelompok KKN 74)

Kegiatan penyuluhan berlangsung pada tanggal 15 Januari 2019. Jumlah peserta yang hadir 42 orang. Respon warga sangat baik terhadap produk unggulan desa dapat dibuktikan dari antusiasnya tanya jawab terhadap produk unggulan dari segi kemasan maupun cara pembuatan. Desa Patereman merupakan desa penghasil buah sawo di Kecamatan Modung Bangkalan. Rasa buah sawo yang manis membuat buah ini banyak penggemarnya. Rasa manis ini disebabkan kandungan dalam daging buah sawo. Daging buah sawo terkandung pula lemak, protein, vitamin $\mathrm{A}, \mathrm{B}$, dan $\mathrm{C}$, mineral besi, kalsium, serta fosfor. Buah sawo memiliki kandungan mineral cukup baik. Kandungan kaliumnya 193 mg/100 g. sawo juga memiliki kadar natrium, $12 \mathrm{mg} / 100 \mathrm{~g}$, perbandingan kandungan kalium dan natrium yang mencapai 16:1 menjadikan sawo sangat baik untuk jantung dan pembuluh darah. Maka dari itu dilakukan inovasi memanfaatkan buah sawo sebagai selai dan kripik sawo.
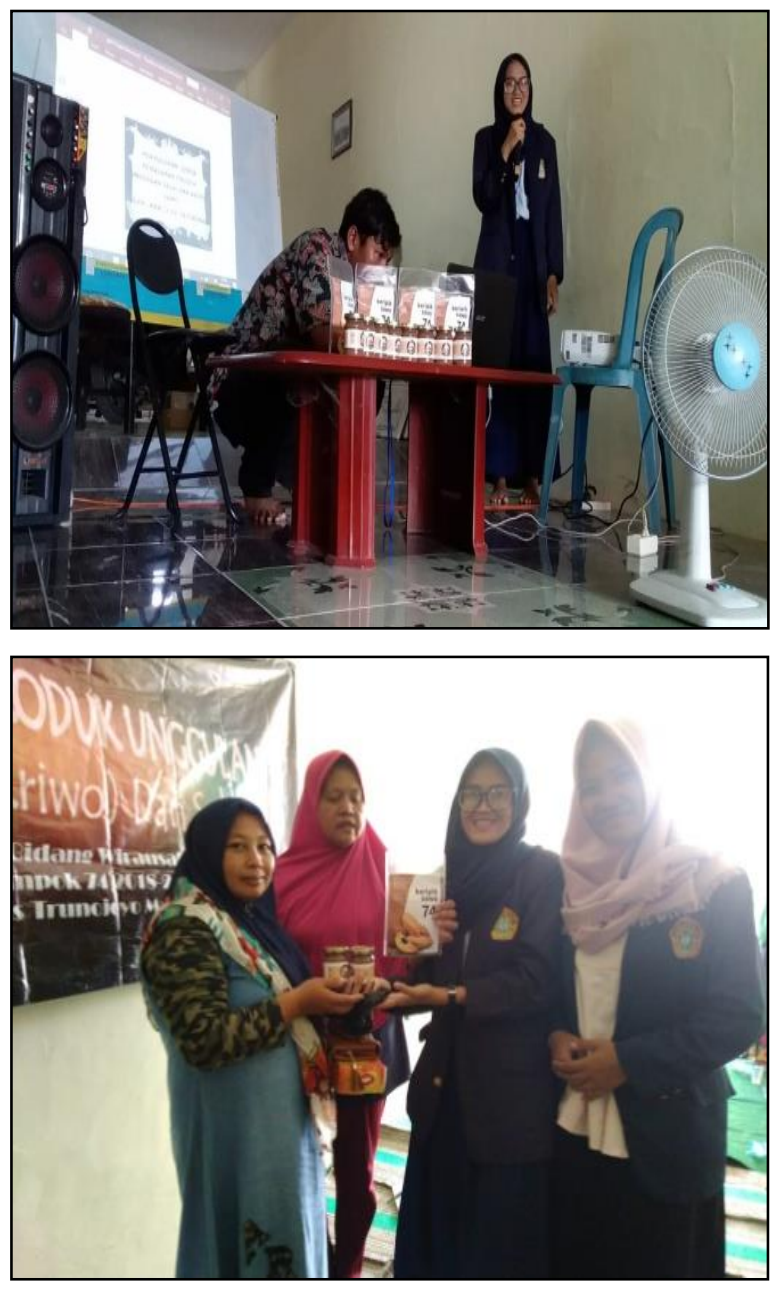

Gambar 3. Pelatihan Pengolahan Buah Sawo 
Produk unggulan tersebut baik untuk kesehatan disebabkan oleh sawo yang memiliki kandungan lemak; protein; vitamin A, B, dan C; mineral besi, kalsium, serta fosfor. Hasil olahan sawo ini bernilai jual tinggi serta dapat meningkatkan kreativitas masyarakat untuk mengembangkan olahan dari buah sawo.

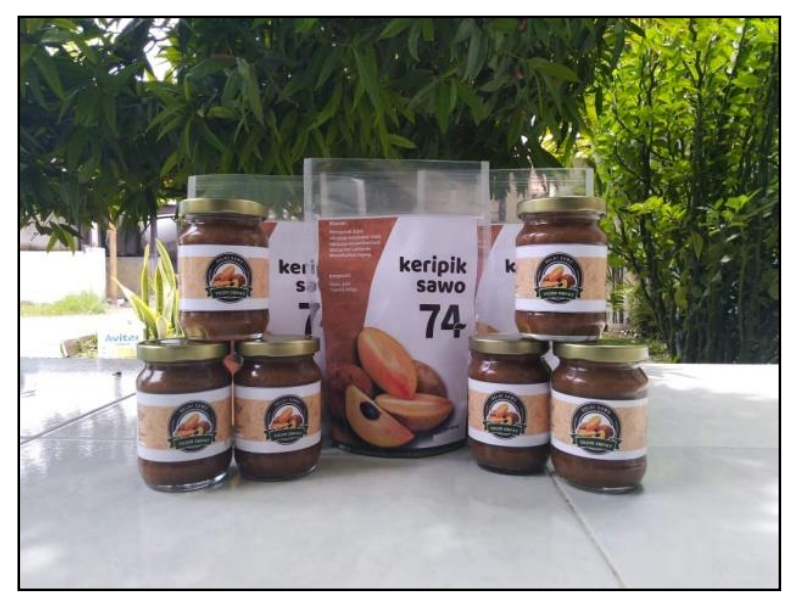

Gambar 4. Kemasan Produk Olahan Sawo

\section{c. Produk unggulan Desa Neroh : stik nasi, kerupuk nasi, dan selai kacang (kelompok KKN 73)}

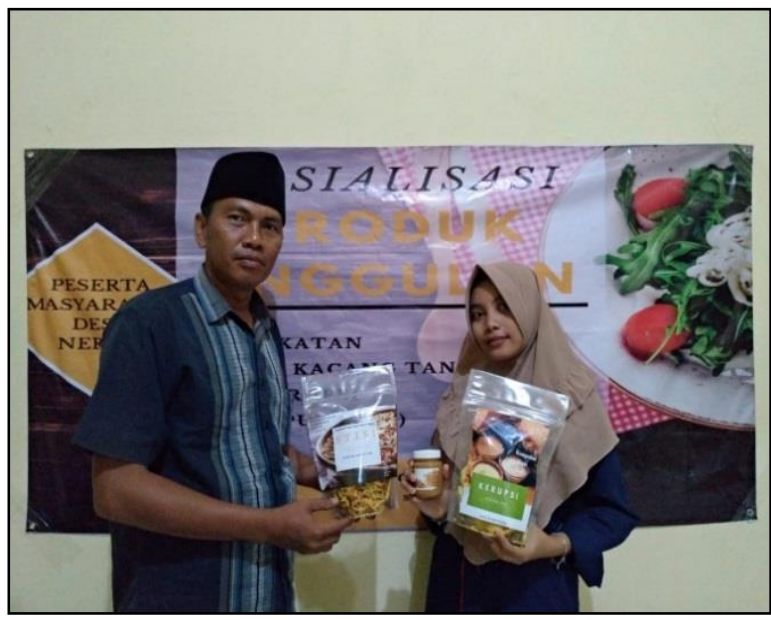

Gambar 5. Produk Stik Nasi, Kerupuk Nasi dan Selai Kacang

Sosialisasi program Produk Unggulan (STISI (Stik Nasi), KERUPSI (Kerupuk Nasi) dan Selai Kacang) dilaksanakan pada tanggal 13 Januari 2019. Program unggulan dilakukan deangan cara pelatihan kepada masyarakat Desa Neroh, terutama ditujukan kepada ibu-ibu warga Desa Neroh agar ilmu yang disampaikan dapat menyeluruh dan dapat diimplementasikan. Pelatihan yang dilakukan adalah praktek pembuatan STISI (Stik Nasi), KERUPSI (Kerupuk Nasi) dan Selai Kacang secara langsung satu persatu. Sosialisasi produk unggulan juga meliputi pembahasan permodalan, pengemasan, dan pemasaran. STISI (Stik Nasi), KERUPSI (Kerupuk Nasi) dan Selai Kacang dipilih sebagai produk unggulan karena potensi utama dari Desa Neroh adalah kacang-kacangan dan bahan pokok yaitu padi.
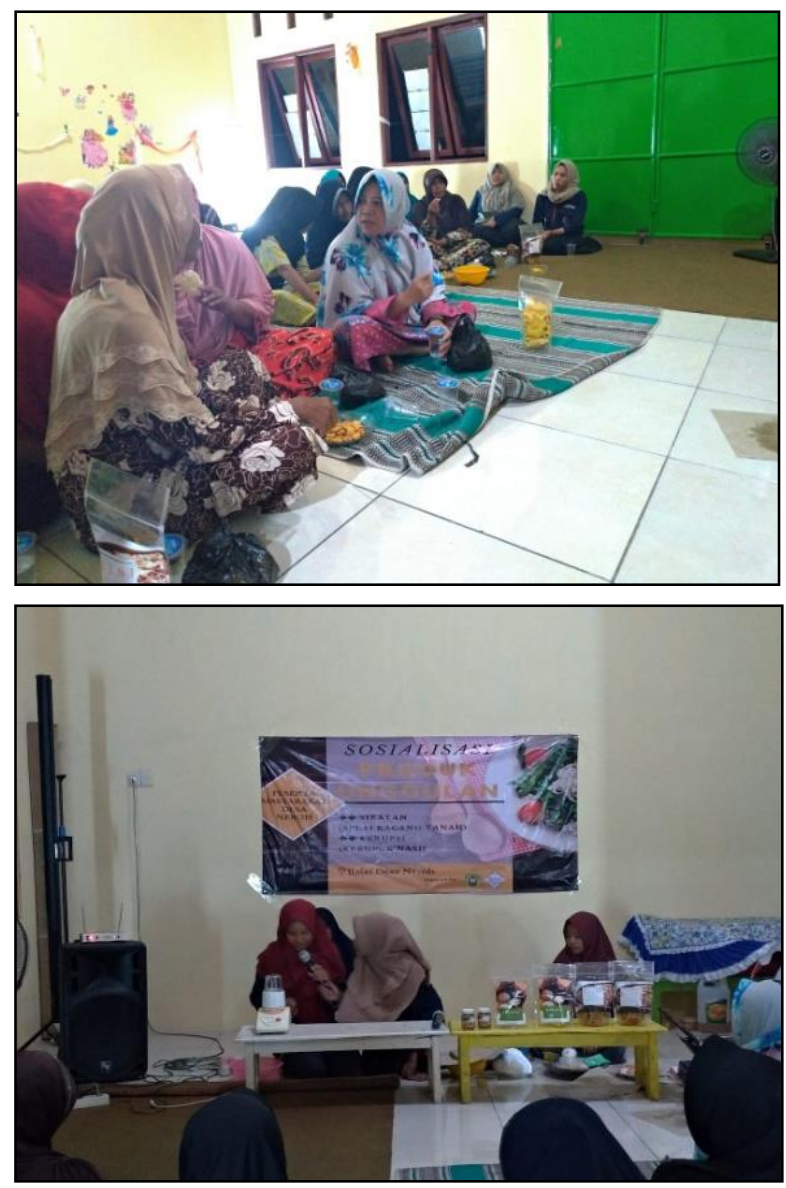

Gambar 6. Kegiatan Sosialisasi dan Pelatihan oleh Mahasiswa KKN

Berdasarkan hasil kegiatan-kegiatan tersebut diatas, maka dapat dirumuskan rencana tindak lanjut sebagai berikut :

1. Melakukan pengawasan dan monitoting secara keberlanjutan dari pihak pejabat desa setempat terhadap produk unggulan desa tersebut agar terus berjalan.

2. Memperkuat kerjasama kelembagaan antara pihak desa dengan LPPM UTM selaku penyelenggara KKN untuk peningkatakan produk unggulan tersebut seperti proses pemasaran, pendampingan dan sebagainya.

3. Membangun kesadaran masyarakat setempat agar mampu mengolah sumber potensi yang ada sehingga mampu menciptakan lapangan 
kerja untuk peningkatan perekonmian dan kesejahteraan masyarakat.

\section{KESIMPULAN}

Kesimpulan dari kegiatan pengabdian masyarakat ini adalah:

1. Kegiatan produk unggulan desa dilakukan di 3 desa lokasi kegiatan KKN di Kecamatan Modung yaitu Desa Paeng, Patereman, dan Desa Neroh.

2. Pada pelaksanaan kegiatan dilakukan proses sosialisasi dan kegiatan pembuatan produk unggulan.

3. Peserta yang ikut dalam pelaksaanan terdiri dari masyarakat desa, Ibu-ibu PKK, dan Karang Taruna.

4. Kegiatan produk unggulan desa mendapat respon yang positif dari seluruh peserta baik masyarakat desa ataupu pejabat desa setempat. Hal ini dibuktikan dengan antusiasnya peserta yang dating dan banyaknya pertanyaan yang diajukan oleh peserta.

5. Harapan dengan kegiatan produk unggulan desa ini mampu memberikan pengetahuan kepada masyarakat untuk mengenali potensipotensi yang ada dan dikembangkan menjadi suatu produk unggulan yang memiliki nilai ekonomis yang tinggi. Selain itu, juga dapat menjadikan indikator pembangunan ekonomi di wilayah tersebut.

\section{DAFTAR PUSTAKA}

Chuzaimah \& Mabruroh. 2008. Identifikasi Produk Unggulan Berbasis Ekonomi Lokal Untuk Meningkatkan Pada Era Otda. Jurnal Berkala Ilmiah Efisiensi. Vol 14 (3).

Malinda, Y. 2014. Analisis Potensi Ekonomi Daerah dalam Pengembangan Komoditi Unggulan Kabupaten Agam. Economica: Jurnal Program Studi Pendidikan Ekonomi STKIP PGRI Sumatera Barat. Vol 3(1).

Pantow, S. Palar, S. \& Wauran, P. 2015. Analisis Potensi Unggulan dan Daya Saing Sub Sektor Pertanian di Kabupaten Minahasa. Jurnal Berkala Ilmiah Efisiensi. Vol 15(4).

Hidayah, I., 2010. Analisis Prioritas Komoditas Unggulan Perkebunan Daerah Kabupaten Buru (Pre-eminent Commodity Preference Analysis of Plantation of Sub-Province Buru). AGRIKA Vol 4(1). 